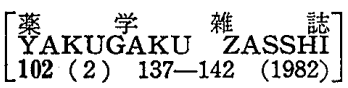

\title{
ヒドロキシアパタイトに対する塩化セチルピリジニウムの吸着
}

\author{
嶋林三郎, 田村知津子, 中垣正幸* \\ 京都大学薬学部
}

\section{Adsorption of Cetylpyridinium Chloride to Hydroxyapatite}

\author{
Saburo Shimabayashi, Chizuko Tamura, and Masayuki Nakagaki* \\ Faculty of Pharmaceutical Sciences, Kyoto University, Yoshida-Shimoadachi-cho, \\ Sakyo-ku, Kyoto 606, Japan
}

(Received September 14, 1981)

\begin{abstract}
Adsorption of cetylpyridinium chloride (CPC) to hydroxyapatite (HAP) was studied. The amount of adsorbed $\mathrm{CPC}$ increased and decreased with the amount of added $\mathrm{NaOH}$, and added $\mathrm{NaCl}$ or $\mathrm{CaCl}_{2}$, respectively. It was assumed that cetylpyridinium cation $\left(\mathrm{CP}^{+}\right)$is adsorbed to negatively charged sites on HAP surface by electrostatic force. Adsorption of anions such as $\mathrm{OH}^{-}$makes the number of adsorption sites for $\mathrm{CP}^{+}$increase on the surface of HAP (cooperative adsorption). But the effect of $\mathrm{Cl}^{-}$anion, which may increase the amount of $\mathrm{CP}^{+}$adsorption, was assumed to be smaller than that of $\mathrm{Na}^{+}$ cation, which decreases the amount of $\mathrm{CP}^{+}$adsorption, because $\mathrm{NaCl}$, as a whole, inhibits $\mathrm{CP}^{+}$adsorption. Cations such as $\mathrm{Na}^{+}$and $\mathrm{Ca}^{2+}$ compete with $\mathrm{CP}^{+}$for the adsorption site charged negatively on HAP (competitive adsorption). The effect of $\mathrm{Ca}^{2+}$ was more remarkable than that of $\mathrm{Na}^{+}$, since $\mathrm{Ca}^{2+}$ is one of the lattice ions of $\mathrm{HAP}$ crystal. As the affinity of $\mathrm{Ca}^{2+}$ to HAP is stronger than that of $\mathrm{CP}^{+}$, the adsorption isotherm of $\mathrm{Ca}^{2+}$ became just one curve irrespective of concentration of $\mathrm{CP}^{+}$added. The fact mentioned above may be one of the reasons why hard tissues and renal calculi adsorb $\mathrm{Ca}^{2+}$ selectively from body fluid containing many kinds of organic and inorganic ions, and grow up in our human body.
\end{abstract}

Keywords--hydroxyapatite; adsorption of cetylpyridinium chloride; adsorption of hydroxyl ion; adsorption of calcium ion; cooperative adsorption; competitive adsorp. tion; renal calculus; hard tissue

ヒドロキシアパタイト ( $\mathrm{HAP})$ は $\mathrm{Ca}_{10}\left(\mathrm{PO}_{4}\right)_{6}(\mathrm{OH})_{2}$ の化学組織を有する塩基性リン酸カルシウムであって, 骨, 歯の主成分であり，また尿路結石の成分の 1 つでもある，この HAP に対する界面活性剤，あるいは電離基 または極性基をもつ有機物質の吸着の研究は従来より多岐にわたうてなされてきた。

まず薬学あるいは歯学の領域に拈いては, ウ崡予防を目的とした基礎研究として，抗菌作用あるいは歯坧沈着 防止作用をもつアルキルアミンのウンデシレン酸塩やフッ化水素酸塩, ${ }^{1}$ あるいはクロールヘキシジン誘導体 ${ }^{2}$ の吸着の研究がなされている. また，塩化アルキルアンモニウムが吸着すると，鎖長が大になると共に HAP の 溶解速度が低下するが,3) HAP を主成分としている歯のエナメル質を硫酸ドデシルナトリウム水溶液で処理した 後に塩酸でェッチングすると末処理の場合に比べてェッチングされやすいことが指摘されている.4

一方，骨や歯に含まれている生体高分子と HAP との結合機構を解明するために，生体高分子の単純化したも デル物質として脂肪酸5)やアミノ酸 ${ }^{6)}$ の HAP に対する結合を研究した結果，カルボキシル基はHAP 表面のカ ルシウムイオンと，プロトン化したアミノ基はHAP 表面にあるリン酸イオンまたは水酸化物イオンと，静電的 に結合していると結論された．これは，臭化セチルトリメチルアンモニウムあるいは臭化セチルピリジニウムの HAP に対する吸着と共に HAP に対する水の接触角が大になること，すなわち䠅水基を水相側へ，荷電基を HAP 表面へ配向させて吸着しているとする結果〉と結論を一にしている.

工業的には，界面活性剤の吸着に伴って水の接触角が大になることを利用してリン鉱石中に含まれているアパ タイトを脈石から分離するのに浮選法が用いられる. ${ }^{8)}$ また, 精糖用骨炭に含まれている HAP と炭素の各表面 
積を界面活性剂の吸着量から算出しょらとする試みもなされている.9

前報 ${ }^{10)}$ に扣いて無機カチオンの HAP に対する吸着性を調べ，アルカリ金属イオンではことに $\mathrm{Na}^{+}$の，アル カリ土類金属イオンではことに $\mathrm{Ca}^{2+}$ の吸着量が大であることを結論した. 本報では, 有機カチオンであるセチ ルピリジニウムイオン $\left(\mathrm{CP}^{+}\right)$の HAP に対する吸着等温線を求め, これに対する共存する $\mathrm{Na}^{+}, \mathrm{Ca}^{2+}, \mathrm{OH}^{-}$の 影響について考察する.

\section{実験 の 部}

試料ヒドロキシアパタイト (HAP) は前報に用いたのと同一の試料である..$^{10,11)}$

実験に用いた試薬は半井化学または和光純薬より購入した特級試薬である.

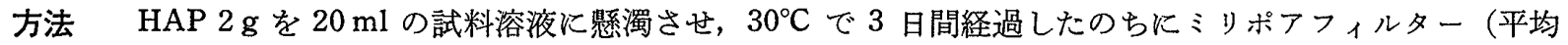
孔径 $0.22 \mu \mathrm{m})$ で沪過し，沪液を分析して HAP に対する吸着量を算出した.

塩化セチルピリジニウム $(\mathrm{CPC})$ の濃度は前報 ${ }^{10)}$ と同様にェプトン法でセチルピリジニウムカチオン $\left(\mathrm{CP}^{+}\right)$ の濃度を分析して求めた。

カルシウムイオン濃度は, 1-(2-hydroxy-4-sulfo-1-naphthylazo)-2-hydroxy-3-naphthoic acid（ドータイトNN 希釈溶液）を指示薬にして $\mathrm{pH} 13$ で EDTA 標準液を用いてキレート滴定法によって求めた，共存する CPC が 指示薬の発色を妨害する時には当量あるいはやや過䣋の硫酸ドデシルナトリウムを加兄て硫酸ドデシルセチルピ リジニウムの沈澱を生じさせたのちにキレート滴定を行った。

吸着量は, 科りこんだ吸着質全濃度と吸着平衡時の遊離平衡吸着質濃度の差, および秤りこんだ HAP の重量 より算出した.

顕微鏡電気泳動 三田村理研工業製顕微鏡電気泳動装置 Model 5-160 を用い，前報11) と同様にして HAP 粒子の電荷の符号を判定した.

結果

\section{CPC の吸着等温線}

Fig. 1 は種々の電解質の共存下に拈けるセチルピリジニウムカチオン $\left(\mathrm{CP}^{+}\right)$の HAP に対する吸着等温線で ある. 添加塩の共存しない場合 $(\mathrm{O})$ 飞比べ $\mathrm{NaCl}$ を $5 \mathrm{~mm}$ 添加すると $(\Theta)$ 吸着量 $X_{\mathrm{CP}}+$ は低下する. しかし $\mathrm{NaCl}$ と $\mathrm{NaOH}$ とがそれぞれ $2.5 \mathrm{mM}$ 共存する場合 $(\mathbf{O})$ ，あるいは $\mathrm{NaOH}$ が $5 \mathrm{~mm}$ 共存する場合 (O) 飞は無添 加の場合 $(O)$ 上りも $X_{\mathrm{CP}^{+}}$は大となる. すなわち, 添加した $\mathrm{Na}^{+}$濃度とイオン強度が一定であるこれらの場合

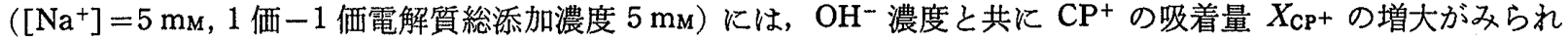

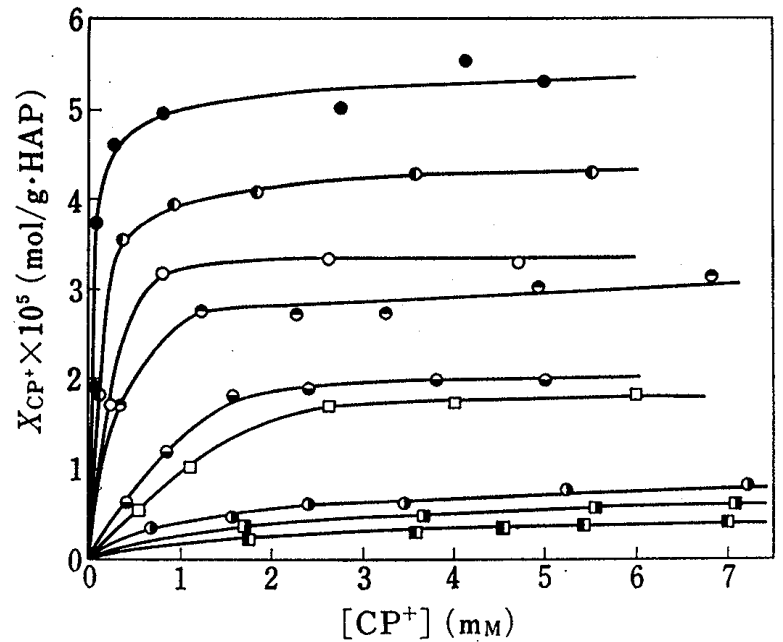

Fig. 1. Adsorption Isotherms of Cetylpyridinium Ion, $\mathrm{CP}^{+}$

Additives (mM): $\bigcirc$ none, $\odot \mathrm{NaCl} 5.0, \odot \mathrm{NaCl} 25$,

$\mathrm{NaCl} 50, \quad \mathrm{NaCl} 2.5+\mathrm{NaOH} 2.5$

$\mathrm{NaOH} 5.0, \square \mathrm{CaCl}_{2} 1.0, \square \mathrm{CaCl}_{2}$ 5.0,

$17 \mathrm{CaCl}_{2} 25$.
る.

一方, $\mathrm{NaCl}$ 添加濃度が $5.0 \mathrm{~mm}(\Theta), 25 \mathrm{~mm}$

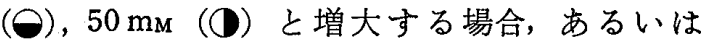
$\mathrm{CaCl}_{2}$ 添加濃度が $1.0 \mathrm{~m}_{\mathrm{M}}(\square), 5.0 \mathrm{~m}_{\mathrm{M}}$ (四), 25 $\mathrm{mM}_{\mathrm{M}}$ (D) と増大する場合には $X_{\mathrm{CP}}+$ は添加量と共 に低下している.

Fig. 1 に示す $\mathrm{CP}^{+}$の吸着等温線はラングミュ アー型になるので, 飽和吸着量 $X_{\mathrm{CP}^{+}, \infty}$ と結合定 数 $k_{\mathrm{CP}}+$ をとれぞれの曲線について求め, 添加電 解質濃度に対する関係をみたのが Fig. 2(A)，(B) である. 少量の $\mathrm{CaCl}_{2}$ の添加で著しく, $\mathrm{NaCl} の$ 添加で直線的にゆるやかに $X_{\mathrm{CP}^{+}, \infty}$ と $k_{\mathrm{CP}^{+}}$とが 低下するのがみられる. $\mathrm{NaOH}$ の添加によっては 両者のパラメーターが増大するのがみられる.

\section{$\mathrm{NaOH}$ 添加の影響}

Fig. 3 には $\mathrm{NaOH}$ 添加にともなら $\mathrm{CP}^{+}$の吸着 量 $X_{\mathrm{CP}}+$ の変化を示した. 横軸は添加した $\mathrm{NaOH}$ 
(A)

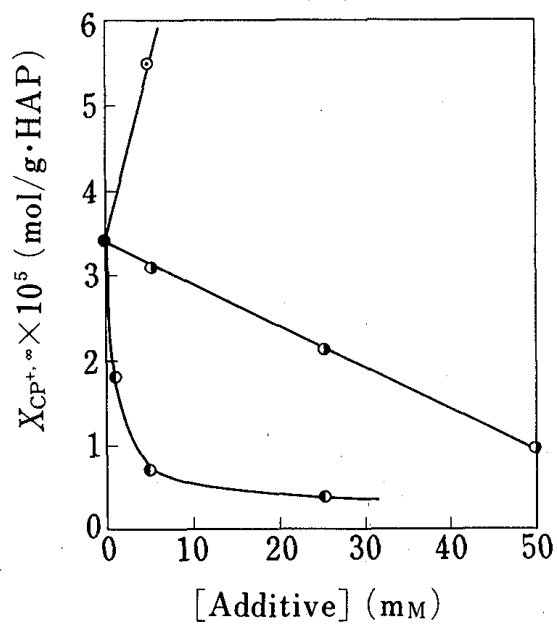

(B)

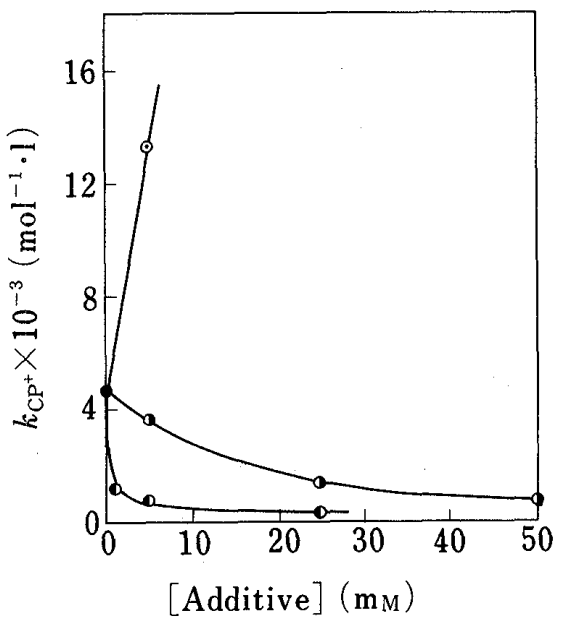

Fig. 2. Relationship between Additive Concentration and $X_{\mathrm{CP}^{+}}$, or $k_{\mathrm{CP}^{+}}$ Additives: - $\mathrm{CaCl}_{2}, \odot \mathrm{NaCl}, \odot \mathrm{NaOH}$.

(A)

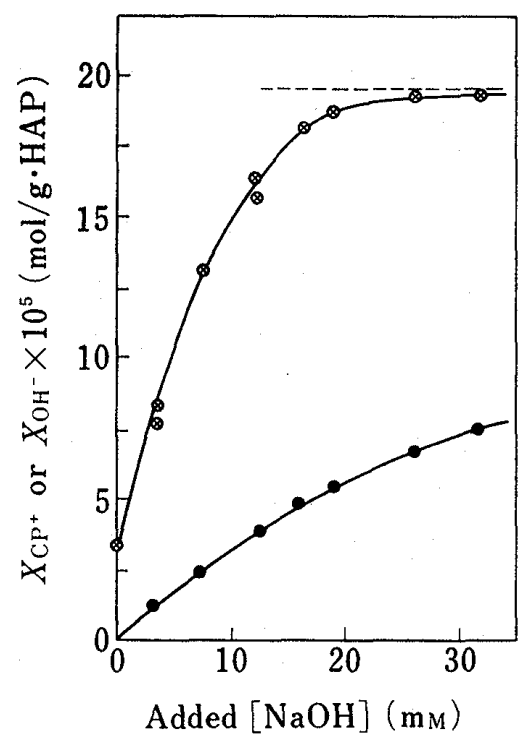

(B)

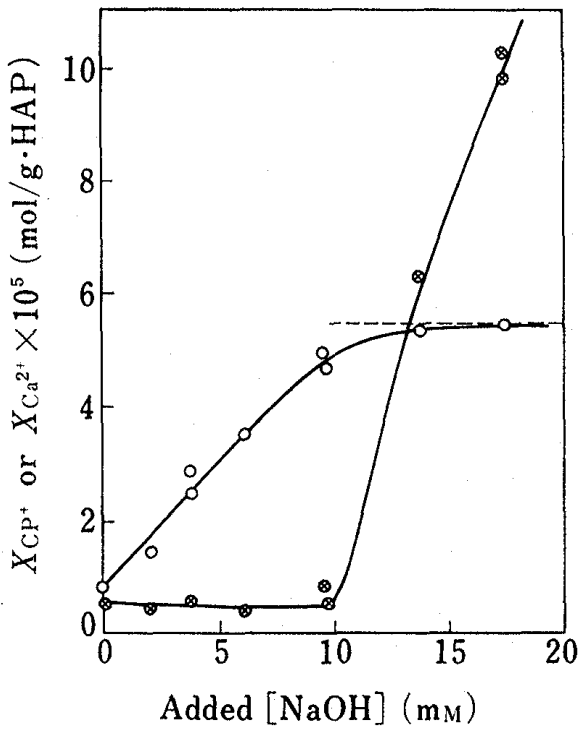

Fig. 3 The Effect of Added $\mathrm{NaOH}$ on the Amount of Adsorbed $\mathrm{CP}^{+}$or $\mathrm{Ca}^{2+}$

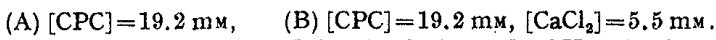

$\otimes: \mathrm{CP}^{+}$adsorbed, $\mathrm{O}: \mathrm{Ca}^{2+}$ adsorbed, $\mathrm{OH}^{-}$adsorbed.

の濃度である. (A) には CPCを $19.2 \mathrm{mM}$ 添加し, それに $\mathrm{NaOH}$ を添加していく時の $\mathrm{CP}^{+}$と $\mathrm{OH}^{-}$の吸着量 $X_{\mathrm{CP}^{+}}, X_{\mathrm{OH}^{-}}{ }^{-}$の変化が示してある. $\mathrm{NaOH}$ の添加量あるいは吸着量の増大と共に $X_{\mathrm{CP}^{+}}$は増大し; $\mathrm{NaOH}$ 添加 濃度約 $15 \mathrm{mM}$ で添加した $\mathrm{CPC}$ の約 90\% が吸着され, 25-30 mM の NaOH の添加でほとんどの CPC が HAP に吸着される、破線は全ての CPC が吸着された場合の吸着量の位置を示している． $\mathrm{OH}^{-}$のみが吸着する場合 であれば $\mathrm{NaOH}$ の添加量と共に（pH の増大と共に） $\mathrm{HAP}$ 粒子の負荷電が増大するのであるが，図に示すよう に $X_{\mathrm{OH}^{-}}$よりも $X_{\mathrm{CP}^{+}}$の方が大であるので媒質の $\mathrm{pH}$ が高いにもかかわらず $X_{\mathrm{CP}^{+}}$の増大と共に HAP 粒子の 正電荷が増大することを顕微鏡電気泳動法で確認した.

Fig. 3 (B) は $19.2 \mathrm{mM}$ CPC と $5.5 \mathrm{mM} \mathrm{CaCl}_{2}$ とが共存する場合の $\mathrm{CP}^{+}$と $\mathrm{Ca}^{2+}$ の吸着量 $X_{\mathrm{CP}^{+}}, X_{\mathrm{Ca}^{2+}}$ の変化 である. $\mathrm{NaOH}$ の添加全濃度が $10 \mathrm{mM}$ 《達するまでは $\mathrm{Ca}^{2+}$ の吸着量（○）はほとんど直線的に増加し，この $\mathrm{NaOH}$ 濃度で添加 $\mathrm{Ca}^{2+}$ 量の約 $90 \%$ が吸着される.この間には $\mathrm{CP}^{+}$の吸着量 (囚) はきわめてゆるやかに低下 

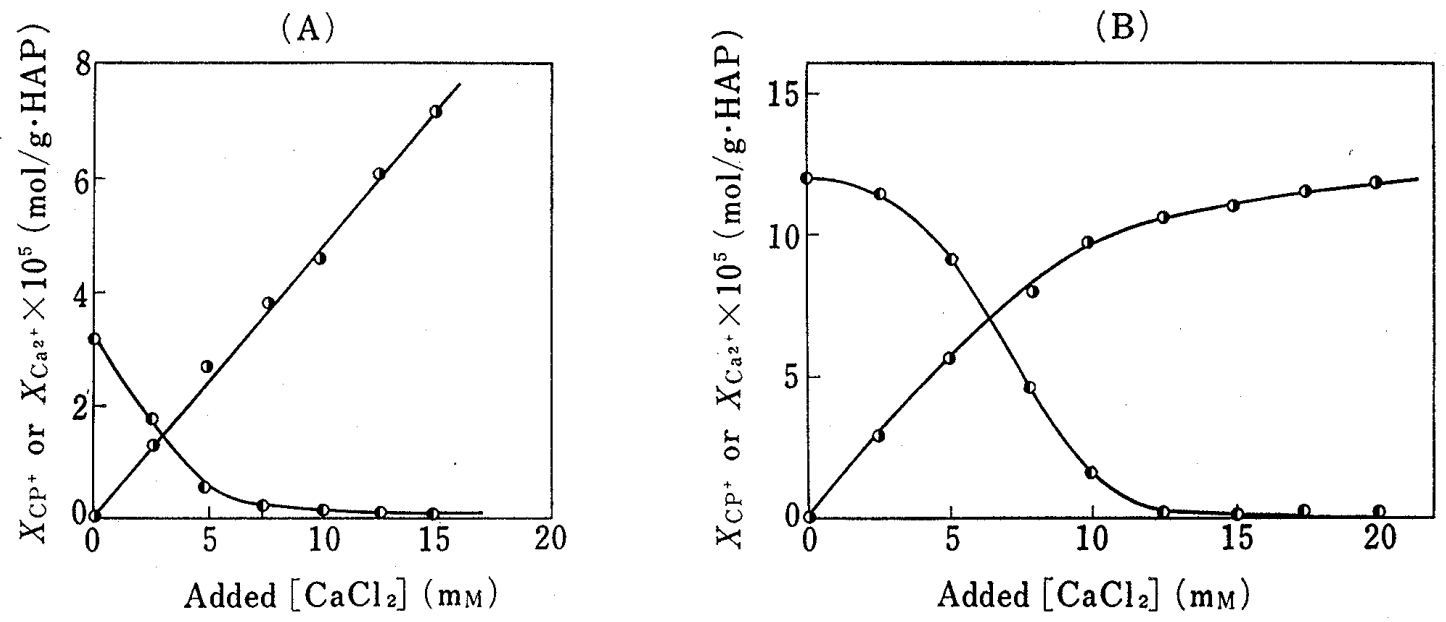

Fig. 4. The Effect of Added $\mathrm{CaCl}_{2}$ on the Amount of $\mathrm{CP}^{+}$adsorbed

(A) $[\mathrm{CPC}]=19.2 \mathrm{~mm},\left[\mathrm{CaCl}_{2}\right][\mathrm{NaOH}]=1.0(\mathrm{~mol} / \mathrm{mol})$,

(B) $[\mathrm{CPC}]=11.5 \mathrm{~mm},[\mathrm{NaOH}]=19.7 \mathrm{~mm}$

(1) $\mathrm{Ca}^{2+}$ adsorbed, $\mathrm{D}: \mathrm{CP}^{+}$adsorbed.

している. 添加した $\mathrm{Ca}^{2+}$ が全て吸着される場合の吸着量を示す破線 (……) 飞 $\mathrm{Ca}^{2+}$ の吸着量が漸近しはじぬ, 溶液中に残存する $\mathrm{Ca}^{2+}$ の濃度が十分に小になったのちに $\mathrm{CP}^{+}$の吸着量の増大がはじまり, 凤で示す曲線が急 激に上昇する。すなわら， $\mathrm{CP}^{+}$と $\mathrm{Ca}^{2+}$ とが共存する場合には $\mathrm{Ca}^{2+}$ の吸着が $\mathrm{CP}^{+}$の吸着よりも優先されること を示している.

\section{$\mathrm{CaCl}_{2}$ 添加の影響}

Fig. 3 亿打いては $\mathrm{CaCl}_{2}$ の添加量は一定であったが, Fig. 4 には $\mathrm{CaCl}_{2}$ の添加量の $\mathrm{CPC}$ の吸着量に括よぼ す影響が示してある. (A) は $\mathrm{CPC}$ 濃度を $19.2 \mathrm{~mm}$ に一定にし, $\mathrm{CaCl}_{2}$ と $\mathrm{NaOH}$ のモル濃度比が 1.0 になるよ うにして $\mathrm{CaCl}_{2}$ の濃度を変化させた場合の結果である. $\mathrm{Ca}^{2+}$ の吸着量は直線的に增加し, $\mathrm{CP}^{+}$の吸着量は $\mathrm{Ca}^{2+}$ の添加量と共に（したがって $\mathrm{OH}^{-}$の添加量とともに）低下してほとんど0になるのがみられる。

(B) は, $\mathrm{CPC}$ 添加濃度と $\mathrm{NaOH}$ 添加濃度をそれぞれ $11.5 \mathrm{mM}, 19.7 \mathrm{mM}$ に一定にした時の $\mathrm{CP}^{+}$と $\mathrm{Ca}^{2+}$ の吸 着量の変化である. (A) の場合と同様に, $\mathrm{CP}^{+}$の吸着量は $\mathrm{CaCl}_{2}$ の添加量は共に低下し, $\mathrm{Ca}^{2+}$ の吸着量は增大 する. 後者は, 横軸が添加全 $\mathrm{Ca}^{2+}$ 濃度で示してあるが $\mathrm{CPC}$ と $\mathrm{NaOH}$ とが共存する場合の $\mathrm{Ca}^{2+}$ の吸着等温線 でもある。

Fig. 5 は $\mathrm{NaOH}$ が $20 \mathrm{~mm}, \mathrm{CPC}$ が種々の濃度共存する場合の $\mathrm{Ca}^{2+}$ の吸着等温線である. この吸着等温線は 共存する CPC の濃度の影響をうけずに 1 本のラングミュアー型吸着等温線で表わされ, 飽和吸着量 $X_{\mathrm{Ca}^{2+}, \infty}$ は $11.5 \times 10^{-5} \mathrm{~mol} / \mathrm{g}-\mathrm{HAP}$, 結合定数 $k_{\mathrm{Ca}^{2}}+$ は $14.3 \times 10^{3} 1 / \mathrm{mol}$ となった.

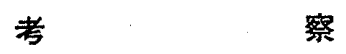

\section{添加電解質による $\mathbf{C P}^{+}$の吸着量の增減}

添加電解質によって塩析が生じる場合, あるいは CPC の活量（近似値としては $\mathrm{CP}^{+}$と $\mathrm{Cl}^{-}$. のイオン積 $\left.\left[\mathrm{CP}^{+}\right]\left[\mathrm{Cl}^{-}\right]\right)$にって $\mathrm{CP}^{+}$の吸着量が定まる場合には, 添加塩濃度之共に吸着量 $X_{\mathrm{CP}^{+}}$あるいはみかけの結合 定数 $k_{\mathrm{CP}}+$ は増大寸るが飽和吸着量 $X_{\mathrm{CP}^{+}, \infty}$ は一定のはずである. ${ }^{11,12)}$ しかし Fig. 1, 2 にみられるように $\mathrm{NaCl}$ または $\mathrm{CaCl}_{2}$ の添加に伴って $\mathrm{Cl}^{-}$濃度が増加するにもかかわらず， $X_{\mathrm{CP}^{+}}, X_{\mathrm{CP}^{+}, \infty}, k_{\mathrm{CP}^{+}}$のいずれもが低下して いる.この原因は, $\mathrm{CP}^{+}, \mathrm{Na}^{+}, \mathrm{Ca}^{2+}$ のいずれもが正電荷を有しているので, HAP 表面にある負電荷を有する吸 着サイトに対してこれらのイオンが競争吸着するためと考光られる. ${ }^{10)}$ 一方, Fig. 3(A) にみられるよらに $\mathrm{NaOH}$ の共存によって $\mathrm{CP}^{+}$の吸着量が增大するのは, アニオンである $\mathrm{OH}^{-}$の $\mathrm{HAP}$ に対する吸着 ${ }^{11)}$ にって HAP の表面の負電荷が増し，カチオンである $\mathrm{CP}^{+}$の吸着サイトが形成されるためである.

しかし Fig. 3(A) に上れば $\mathrm{NaOH}$ の共存による $\mathrm{CP}^{+}$の吸着量の増分は $\mathrm{OH}^{-}$の吸着量よりも大きい，これは， $\mathrm{CP}^{+}$は単に吸着 $\mathrm{OH}^{-}$の近傍へ吸着するのみならず, $\mathrm{NaOH}$ の添加と共に $\mathrm{H}_{2} \mathrm{PO}_{4}^{-}$から $\mathrm{HPO}_{4}{ }^{2-}, \mathrm{PO}_{4}{ }^{3-}$, へと 
変化する表面 リン酸基の近傍へも $\mathrm{CP}^{+}$が吸着す るためと考兄られる。 また，HAP 表面で CPC のへミミセルが形成される可能性も考兄られる が, ${ }^{8)}$ 現時点ではこの点に関しては不明である。

上に述べたように $\mathrm{Na}^{+}$自身は $\mathrm{CP}^{+}$の吸着を妨 害するのであるが， $\mathrm{OH}^{-}$の吸着による $\mathrm{CP}^{+}$の吸 着促進効果の方が強いために $\mathrm{NaOH}$ の添加は $\mathrm{CP}^{+}$に詨する吸着促進効果を示す。この理由は, $\mathrm{OH}^{-}$は HAP の格子イオンの 1 つであるので HAP 表面あるい性内部へルムホルッ層で HAP に吸着していると考学られるが，この吸着 $\mathrm{OH}^{-}$ の対イオンである $\mathrm{Na}^{+}$の大部分は外部へルムホ ルッ層あるい性散電気 2 重層に分布していると

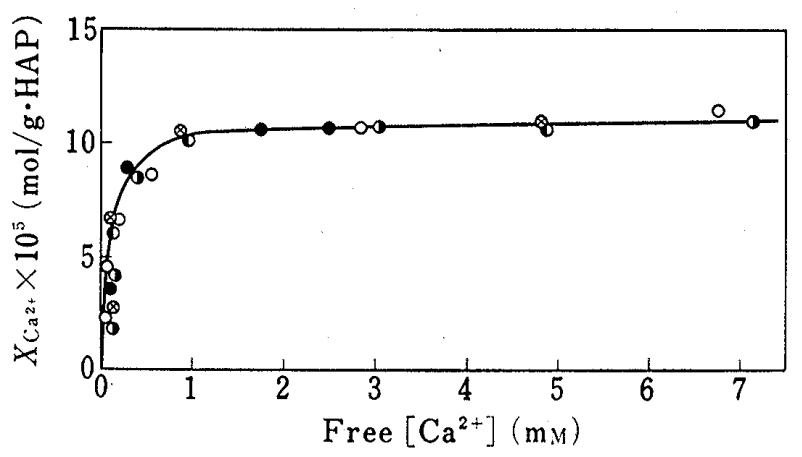

Fig. 5. Adsorption Isotherm of $\mathrm{Ca}^{2+}$ Added $[\mathrm{NaOH}]=20.0 \mathrm{~mm}$, Added $[\mathrm{CPC}](\mathrm{mM})=0.0(\mathrm{O}), 5.0(\otimes), 10.0(\mathrm{O})$, $20.0(\mathbf{D}), 40.0(\bigcirc)$.

考光られるためである.したがって，Fig. 1 にみられるように Na+ 添加濃度を $5 \mathrm{mM}$ に一定にする場合には， $\mathrm{OH}^{-}$添加濃度の増大と共に $\mathrm{CP}^{+}$に対する吸着促進効果が大となり，

○，の，○の順に $\mathrm{CP}^{+}$の吸着量が増大す る.

しかし $\mathrm{OH}^{-}$によって形成される吸着サイトに対しては， $\mathrm{CP}^{+}$と同様にカチオンである $\mathrm{Ca}^{2+}$ む吸着する，乙 かもこの $\mathrm{Ca}^{2+}$ はHAP の格子イオンであるので $\mathrm{CP}^{+}$よりも優先的に HAP に対して吸着する. その結果, $\mathrm{CP}^{+}$ と $\mathrm{Ca}^{2+}$ とが一定濃度加えられている Fig. 3(B) 飞招いては, $\mathrm{OH}^{-}$濃度が増すにもかかわらず $\mathrm{Ca}^{2+}$ が溶液中か らほとんど全量吸着されるまでは $\mathrm{CP}^{+}$の吸着量は増加しない。また，Fig. 4 飞みられるように, $\mathrm{Ca}^{2+}$ 濃度の増 大にともなって $\mathrm{CP}^{+}$の吸着量は低下し，Fig. 5 にみられるように， $\mathrm{Ca}^{2+}$ の吸着等温線は共存する $\mathrm{CPC}$ の濃度 に無関係に一意的に定まる結果となる.

$\mathrm{OH}^{-}$と同様にアニオンである $\mathrm{Cl}^{-}$も $\mathrm{HAP}$ への吸着によってカチオンである $\mathrm{CP}^{+}$に対して吸着促進作用を示 すはずである。しかし $\mathrm{NaCl}$ 水溶液からの $\mathrm{Cl}^{-}$の吸着量が少ないこと，招よび Fig. 1 亿示すように $\mathrm{NaCl}$ が $\mathrm{CP}^{+}$に対して吸着妨害作用を示すことより， $\mathrm{Cl}^{-}$による $\mathrm{CP}^{+}$の吸着促進効果は極く僅かと考光られ，本報では $\mathrm{Cl}^{-}$による作用については無視している.

以上の結果より $\mathrm{CP}^{+}$の吸着に拉よぼす添加イオンの影響についてまとめると， $\mathrm{OH}^{-}$の吸着促進作用は $\mathrm{Na}^{+}$ の吸着妨害作用汇ささ $\mathrm{NaOH}$ は吸着促進剂であるが， $\mathrm{Na}^{+}$の作用は $\mathrm{Cl}^{-}$の吸着促進作用注まさり $\mathrm{NaCl}$ は吸 着妨害剂となる。また $\mathrm{Ca}^{2+}$ の吸着妨害作用は $\mathrm{Na}^{+}$の作用よりも顕著である (Figs. 1, 2)。この序列は, $\mathrm{Ca}^{2+}$ と $\mathrm{OH}^{-}$が $\mathrm{HAP}$ の格子イオンであり， $\mathrm{Na}^{+}$は $\mathrm{Ca}^{2+}$ と結晶イオン半径は似ているが荷電数が小なること,10) および $\mathrm{Cl}^{-}$は HAP 構成アニオンであるりン酸イオンや水酸化物イオンとは結晶イオン半径が異なっていて HAP に対 する親和性が乏しく吸着が生じにくいことによって生じると考兄られる.

上に述べたよらに $\mathrm{CP}^{+}$等の有機カチオンの $\mathrm{HAP}$ に対する吸着量は $\mathrm{pH}$ の増大 $\left(\mathrm{OH}^{-}\right.$濃度の増大) と共に大 となるが， $\mathrm{Ca}^{2+}$ の共存で注小となる、したがってカチオン性界面活性剤あるいはクロールヘキシジン誘導体 ${ }^{22}$ 等の陽イオン性の薬物を HAP に対して有効に結合させるに際しては $\mathrm{pH}$ が大であること拈よび $\mathrm{Ca}^{2+}$ 濃度の低 いことが望むしいといえる.

負電荷を有する生体高分子，たとえば蛋白質や核酸，の分別と精製の目的に HAP のカラムが用いられ，この 際の溶出液としては種々の濃度のリン酸緩衝液が用いられる. ${ }^{13)}$ これは HAP に対する親和性が大きいりン酸イ オンと試料の高分子アニオンとの HAP に対する競争吸着を利用して，吸着している試料アニオンを溶離させる ためである. 同様に考えて $\mathrm{Ca}^{2+}$ の $\mathrm{HAP}$ 飞対する大きな親和性を利用すれば正電荷をもつ試料物質を HAP カ ラムに吸着させ，種々の濃度の $\mathrm{CaCl}_{2}$ 水溶液で溶出させることによって，この物質の分別と精製を行うことがで きると考兄られる.

\section{硬組織の形成と成長}

体内に硬組織あるいは尿路結石の一成分としての HAP の微結晶あるいは結晶核が存在する時, これは体液中 に含まれている種々のイオン性および非イオン性物質と接触して拉り, 結合あるいは吸着する可能性がある. し 
かし前報 ${ }^{10)}$ に示したように，2 洒アルカリ土類金属イオンではことに $\mathrm{Ca}^{2+}$ が，1 価アルカリ金属イオンではこ とに $\mathrm{Na}^{+}$が，他のイオンに比べ優先的に HAP へ取りこまれると考えられている．また本報で上に述べたよう に，有機カチオンと比較しても $\mathrm{Ca}^{2+}$ が優先的に HAP 表面へ取り込をれ吸着される. HAP の結晶成長の微視的 過程は格子イオンの HAP 表面への吸着と考兄られるので, この吸着の結果, 種々のイオンが共存しているにも かかわらず構成カチオンの大部分を $\mathrm{Ca}^{2+}$ とする硬組織あるいは尿路結石が体内で形成され，成長することにな る.

\section{引用文献および注}

1) V.D. Warner, J.N. Sane, A.M. Warner, D.B. Mirth, S. Turesky, B. Soloway, J. Dental Res., 56, 1599 (1977).

2) R.G. Fisher, R.P. Quintana, M.M. Boulware, J. Dental Res., 54, 20, 25 (1975); M. Hata, N. Nambu, T. Nagai, Chem. Pharm. Bull., 29, 1151 (1981).

3) T.J. Roseman, W.I. Higuchi, B. Hodes, J.J. Hefferren, J. Dental Res., 48, 509 (1969).

4) W.J. Hamilton, G. Judd, G.S. Ansell, J. Dental Res., 54, 49 (1975).

5) J.J. Bladon, J. Colloid Interface Sci., 78, 175 (1980).

6) M. Kresak, E.C. Moreno, R.T. Zahradnik, D.I. Hay, J. Colloid Interface Sci., 59, 283 (1977); D.I. Hay, E.C. Moreno, J. Dental Res., 58, special issue B, 930 (1979).

7) H.S. Hanna, F.Z. Saleeb, Colloids and Surfaces, 1, 295 (1980).

8) R.K. Mishra, S. Chander, D.W. Fuerstenau, Colloids and Surfaces, 1, 105 (1980).

9) M.C. Bennett, J.C. Abram, J. Colloid Interface Sci., 23, 513 (1967).

10) S.Shimabayashi, C. Tamura, M. Nakagaki, Chem. Pharm. Bull., 29, 3090 (1981).

11) S.Shimabayashi, C. Tamura, M. Nakagaki, Chem. Pharm. Bull., 29, 3090 (1981).

12) M. Nakagaki, T. Handa, S. Shimabayashi, J. Colloid Interface Sci., 43, 521 (1973).

13) G. Bernandi, Biochim. Biophys. Acta, 174, 449 (1969); G. Bernandi, T. Kawasaki, Biochim. Biophys. Acta, 160, 301 (1968). 